Article

\title{
Oncogenic Potential of Bisphenol A and Common Environmental Contaminants in Human Mammary Epithelial Cells
}

\author{
Vidhya A Nair ${ }^{1}$ (D), Satu Valo ${ }^{2}$, Päivi Peltomäki ${ }^{2}$, Khuloud Bajbouj $^{1}$ and \\ Wael M. Abdel-Rahman 1,3,*(D) \\ 1 Sharjah Institute for Medical Research, University of Sharjah, Sharjah P.O. Box 27272, UAE; \\ vnair@sharjah.ac.ae (V.A.N.); kbajbouj@sharjah.ac.ae (K.B.) \\ 2 Department of Medical and Clinical Genetics, University of Helsinki, FI-00014 Helsinki, Finland; \\ satu.valo@blueprintgenetics.com (S.V.); paivi.peltomaki@helsinki.fi (P.P.) \\ 3 Department of Medical Laboratory Sciences, College of Health Sciences, University of Sharjah, \\ Sharjah P.O. Box 27272, UAE \\ * Correspondence: whassan@sharjah.ac.ae; Tel.: +971-65057556; Fax: +971-65057515
}

Received: 3 April 2020; Accepted: 19 May 2020; Published: 25 May 2020

\begin{abstract}
There is an ample epidemiological evidence to support the role of environmental contaminants such as bisphenol A (BPA) in breast cancer development but the molecular mechanisms of their action are still not fully understood. Therefore, we sought to analyze the effects of three common contaminants (BPA; 4-tert-octylphenol, OP; hexabromocyclododecane, HBCD) on mammary epithelial cell (HME1) and MCF7 breast cancer cell line. We also supplied some data on methoxychlor, MXC; 4-nonylphenol, NP; and 2-amino-1-methyl-6-phenylimidazo [4-b] pyridine, PhIP. We focused on testing the prolonged (two months) exposure to low nano-molar concentrations (0.0015-0.0048 nM) presumed to be oncogenic and found that they induced DNA damage (evidenced by upregulation of pH2A.X, pCHK1, pCHK2, p-P53) and disrupted the cell cycle. Some agents induced epigenetic (methylation) changes of tumor suppressor genes TIMP3, CHFR, ESR1, IGSF4, CDH13, and GSTP1. Obviously, the accumulation of these molecular alterations is an essential base for cancer development. Consistent with this, we observed that these agents increased cellular invasiveness through collagen. Cellular abilities to form colonies in soft agar were increased for MCF7. Toxic agents induced phosphorylation of protein kinase such as EGFR, CREB, STAT6, c-Jun, STAT3, HSP6, HSP27, AMPK $\alpha 1$, FAK, p53, GSK-3 $\alpha / \beta$, and P70S6 in HME1. Most of these proteins are involved in potential oncogenic pathways. Overall, these data clarify the molecular alterations that can be induced by some common environmental contaminants in mammary epithelial cells which could be a foundation to understand environmental carcinogenesis.
\end{abstract}

Keywords: bisphenol A; breast cancer; hexabromocyclododecane; methoxychlor; nonylphenol; octylphenol

\section{Introduction}

Breast cancer incidence has been generally rising over the last 50 years with rapid increases observed particularly in developing countries [1-3]. Interestingly, developing countries show a higher incidence of breast cancer in urban compared to rural areas [4]. Furthermore, studies showed that women who migrate from low incidence to high incidence environment tend to develop breast cancer at higher rate than before supporting the hypothesis that breast cancer risk is strongly associated with environmental factors [5,6]. The Breast Cancer Fund report entitled "State of the Evidence: The Connection Between Breast Cancer and the Environment" released in October 2010 stresses upon the growing evidence linking breast cancer to a wide range of environmental exposures including 
bisphenol A (BPA) in food containers. Examples of other exposures include 4-nonylphenol (NP), 4-tert-octylphenol (OP), methoxychlor (MXC), and hexabromocyclododecane (HBCD); all of which could mimic estrogenic action and hence act as "endocrine disruptors" [7]. Additionally, environmental exposures include other contaminants of our food and drink such as the common food carcinogen 2-amino-1-methyl-6-phenylimidazo [4-b] pyridine (PhIP) which is a heterocyclic amine formed during the high-temperature cooking of meat and is known as a "cooked-meat mutagen" [8-10].

BPA is a synthetically produced chemical plasticizer that is commonly used in the production of polycarbonate plastics and epoxy resins which line various containers for foods, drinks, baby bottles, and water tanks. Human exposure to BPA occurs mainly through consumption of canned food and drinks because BPA migrates from the containers into the contents when heated or even under normal conditions of use. The endocrine disrupting action of BPA can be explained by its weak binding affinity for the estrogen receptors, $\mathrm{ER} \alpha$ and $\mathrm{ER} \beta[11,12]$. BPA is also able to induce activation of Erk1/2 in human breast cancer cells through activation of G protein-coupled receptor 30 (GPR30) [13]. BPA can induce a complex set of signaling which cannot be explained by its binding to estrogen receptors only and it exerts many of these effects at low doses even lower than the current "safe" exposure limit for humans [14-16]. There is a strong evidence to implicate perinatal BPA exposure in mammary cancer development in various animal models and in vitro $[7,15,17,18]$. BPA is also able to induce resistance to doxorubicin, cisplatin, and vinblastine in vitro $[19,20]$.

NP and OP are alkylphenols commonly used in production of laundry and dish detergents, emulsifiers, and solubilizers, as additives for fuels and lubricants, and are also used in making fragrances, antioxidants, and fire-retardant materials. Alkylphenols are xenoestrogens that can exert an endocrine disrupting effect with controversial carcinogenic effect which seems to be lineage specific [21-23]

MXC is a synthetic organochlorine used as an insecticide that was intended to be a replacement for DDT. It was banned in the European Union in 2002 and the US by 2003 based on its acute toxicity. It stimulates the growth of ovarian carcinoma cells in vitro by regulating cell cycle genes and abrogating apoptosis via an ER-dependent pathway [24]. MXC is detected at higher concentrations in breast cancer tissues compared to normal tissues [25] but a full understanding of detailed oncogenic mechanism is still lacking.

HBCD is one of the brominated flame retardants and is a major component of foam that is used as thermal insulation in the building industry, furniture, automobile interior textiles, car cushions, and packaging material. HBCD can induce DNA damage [26], exert endocrine disruption, and enhance growth of cancer cells of various lineages including prostate cancer [27] and ER-positive ovarian cancer [28]. Furthermore, HBCD induced chemo-resistance to cisplatin in a group of hepatocellular carcinoma cells (HepG2, MHCC97H, and MHCC97L) [29].

The role of cooked meat toxins such as PhIP in human breast cancer development is suggested by epidemiological studies and consequently the specific role of PhIP in breast cancer development is proved and attributed to estrogenic effect in some studies [30,31] but debated by others [32].

Thus, clear evidence of mammary cell oncogenicity together with the detailed oncogenic molecular pathways are still lacking for some toxic agents. Furthermore, many studies used already established breast cancer cell lines, which would be difficult to extrapolate on non-malignant (normal, immortalized, or benign) mammary epithelial cells. Therefore, this project aims to clarify the genotoxic/oncogenic effects of these toxic chemicals (with a focus on BPA, HBCD, and OP) in mammary epithelial cells and clarify the molecular pathways of these effects. This study is important to supply evidence-based approach to cancer prevention. 


\section{Results}

\subsection{Environmental Contaminants and Cell Viability}

We first tested different concentrations of toxic agents for their effects on viability. In general, high concentrations $(1-10 \mu \mathrm{M})$ reduced viability while exposure to low nanomolar concentrations of toxic agents (0.0015-0.0048 $\mathrm{nM}$ ) exerted subtle effect on viability; and some counteracted the cytotoxic effect of doxorubicin as compared to control (vehicle-exposed) cells. Therefore, we rather focused on the low concentrations (BPA, MXC, HBCD, NP, OP, PhIP at 0.0043, 0.0028, 0.0015, 0.0045, 0.0048, $0.0044 \mathrm{nM}$, respectively) because of this potential to exert a pro-survival advantage after treatment with the cytotoxic agent doxorubicin (Figure 1). The focus of this work was to analyze the transformation potential on the mammary epithelium which is a long process that naturally might take years, so we opted for a prolonged exposure ( 2 months) after which we performed further functional analyses to dissect the potential long term transformation potentials of these toxic agents particularly on HME1 cells.

(A) MTT assay of HME1 at $48 \mathrm{~h}$ incubation

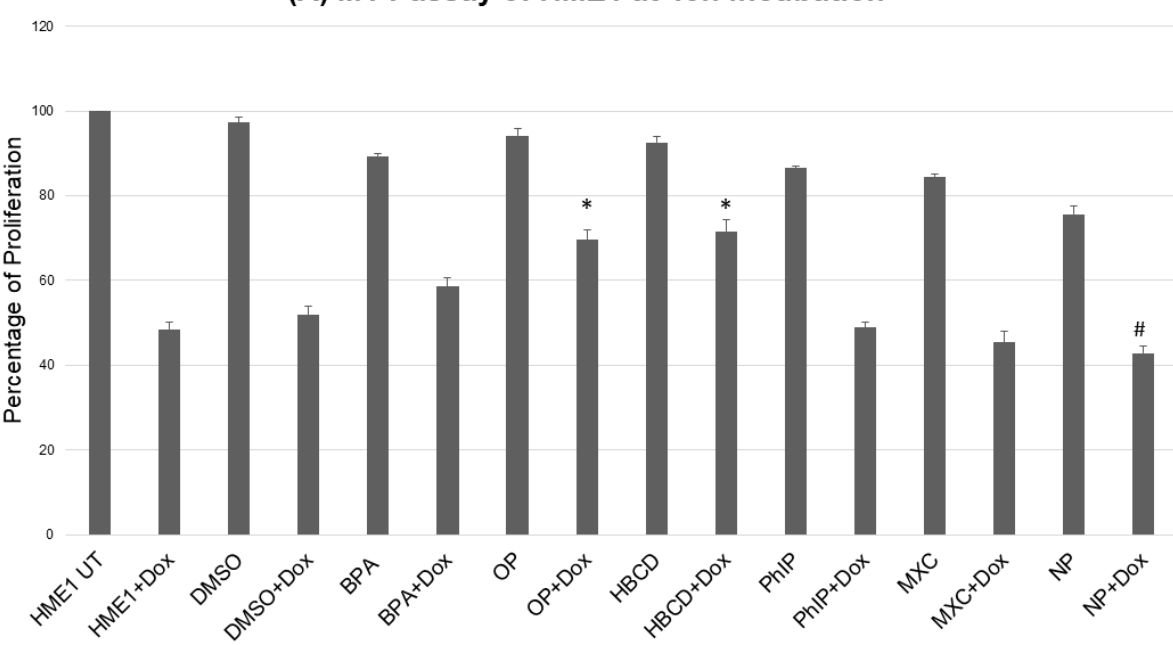

(B) MTT assay of MCF7 at $48 \mathrm{~h}$ incubation

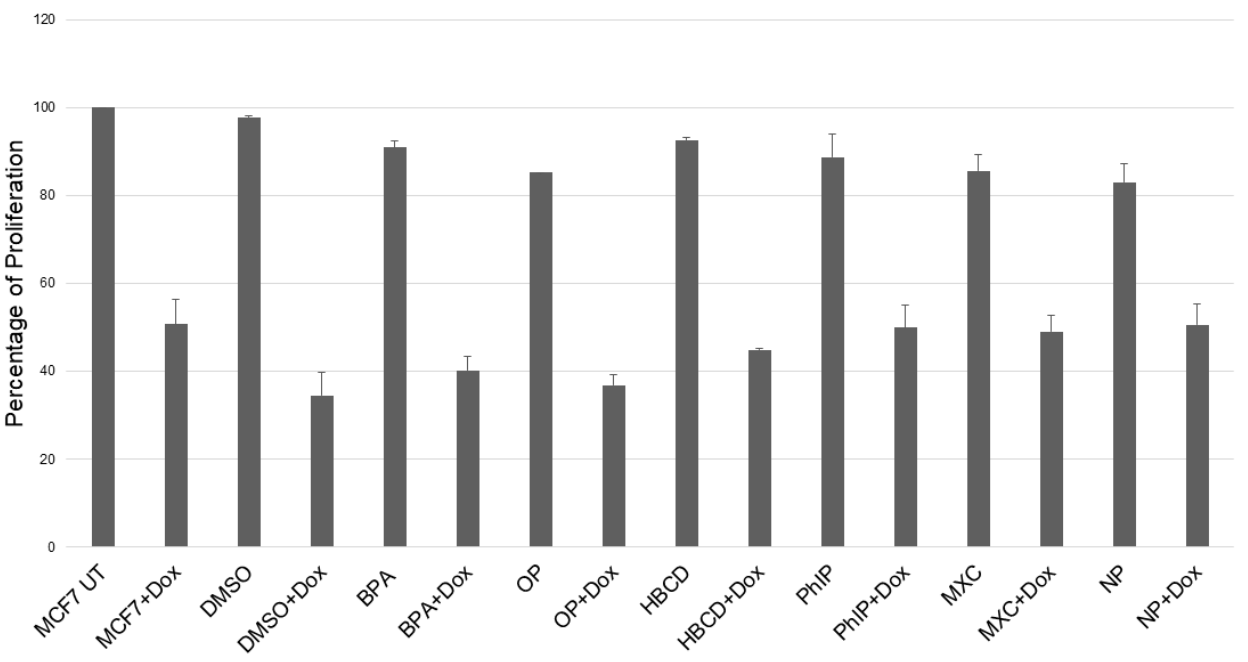

Figure 1. Representative graph showing altered viability of (A) HME1 and (B) MCF7 treated with nanomolar concentrations of various toxic agents (BPA, MXC, HBCD, NP, OP, PhIP at 0.0043, 0.0028, $0.0015,0.0045,0.0048,0.0044 \mathrm{nM}$, respectively) alone or after overnight exposure to a therapeutic concentration of doxorubicin. Of note that, some toxic agents interfered with the killing effect of doxorubicin. Mean $\pm \mathrm{SEM},{ }^{*} p<0.05$, \# indicates a tendency $(p<0.10), n=3$ (3 biological $\times 3$ technical). 


\subsection{DNA Damage by Environmental Contaminants}

DNA damage detection has been optimized and performed using a selection of antibodies against phosphorylated DNA damage markers (p-Chk1, p-Chk2, p-histone H2A.X, p-p53) by Western blotting (Figure 2, Table 1). The experiment was performed on the two-month exposed cells to the low concentration. All 6 agents induced some DNA damage markers. Considering the total number of upregulated markers as a reflection of overall toxicity, the most DNA damaging agents were BPA and OP (8 markers each), followed by HBCD and PhIP (7 markers each), then NP (4 markers), and the least was MXC (3 markers).

Table 1. Induction of DNA damage markers by environmental contaminants.

\begin{tabular}{ccccccccccc}
\hline & \multicolumn{2}{c}{ p-Chk1 } & \multicolumn{2}{c}{ p-Chk2 } & \multicolumn{2}{c}{ p-Histone } & \multicolumn{2}{c}{ p-p53 } & Total Positive \\
Markers
\end{tabular}

Footnote: The gray highlight indicates the positive findings included in the "total". +, weak expression; ++ strong expression, - , no expression.

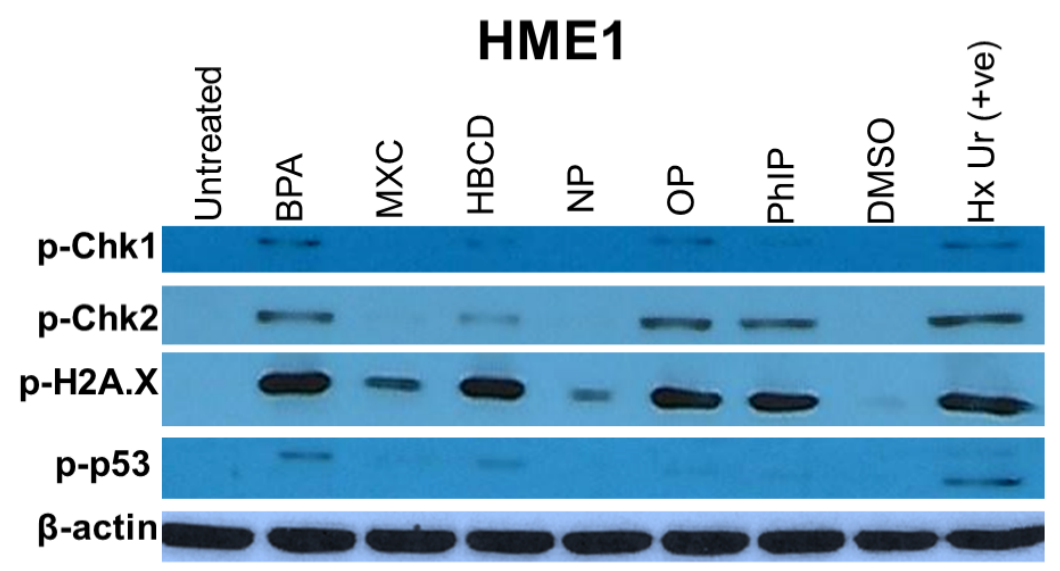

Figure 2. DNA damage response detected in the mammary epithelial cells HME1. Cells were treated with toxic agents (bisphenol A (BPA), methoxychlor (MXC), hexabromocyclododecane (HBCD), 4-nonylphenol (NP), 4-tert-octylphenol (OP), and 2-amino-1-methyl-6-phenylimidazo [4-b] pyridine (PhIP) at $0.0043,0.0028,0.0015,0.0045,0.0048,0.0044 \mathrm{nM}$, respectively) for two months, then the expression of DNA damage response markers were tested by Western blot using antibodies against phospho-Chk1 (Ser345), phospho-Chk2 (Thr68), phospho-p53 (Thr18), and phosph-Histone H2A.X (Ser139). Markers were expressed to various levels in the cells exposed to these nanomolar concentrations of toxic agents for 2 months as compared to the untreated and DMSO control. Hydroxyurea (20 mM) was used as a positive control.

\subsection{Disruption of the Cell Cycle by Environmental Contaminants}

Flowcytometry showed that exposure to environmental contaminants has multiple effects on the cell cycle. However, this effect was variable according to the cell lines, environmental contaminant and duration of exposures, these effects are given in details in Figures S1 and S2. Considering the results from cells exposed to environmental contaminants alone (without treatment with doxorubicin), we found that short exposure $(24 \mathrm{~h}$ ) to environmental contaminants induced mainly G2/M arrest in 
both MCF7 and HME1 with exception of OP in HME1 which increase in G1 peak. Other effects that were also noted after $24 \mathrm{~h}$ such as that BPA, MXC, HBCD, and OP caused increases in S phase in MCF7. After $48 \mathrm{~h}$ HME1was still showing the increase in G2/M but the MCF7 cell showed mainly increase in the G1 or S phases consistent with the expectation that cancer cells may have developed mechanisms to tolerate DNA damage. After 2 months exposure to these agents the MCF7 showed various effects according to each agent with BPA, MXC, HBCD, and NP causing G1 and S phase increases while OP caused G2/M and PhIP caused both S and G2/M phase increases; while HME1 showed an increase in S phase (all agents), G1 (MXC, PhIP), and G2/M (BPA, HBCD, NP, and OP).

It was also noted that exposures to environmental contaminants caused subtle reduction of the sub G1 peak (generally considered as a measure of apoptotic cells) that was induced by exposure to doxorubicin alone; this finding could support the chemo-resistance effect of these agents.

\subsection{Methylation Changes in Tumor Suppressor Genes and LINE1}

We performed these experiments on the cells exposed for two months using a commercial panel (MS-MLPA) which contains 24 well established tumor suppressor genes. Before any treatments, 15 of the 24 tumor suppressor gene loci were unmethylated in the MCF7 breast cancer cells. All loci except one (CDKN2B) were unmethylated in the untreated HME1 mammary epithelial cells. The vehicle control (dimethyl sulfoxide, DMSO) induced some methylation events and hence we reported the methylation in relation to this control. We observed that BPA induced hypermethylation of TIMP3, CHFR, ESR1, and IGSF4 while HBCD induced TIMP3 tumor suppressor gene hypermethylation in MCF7 breast cancer cell line. BPA additionally induced hypermethylation of CDH13 and GSTP1 in HME1 mammary epithelial cells. There were some instances of reduction of methylation of already methylated genes in MCF7 by BPA (CASP8, RASSF1, and GSTP1); therefore, we also tested LINE1 hypomethylation. LINE-1 methylation was slightly decreased in MCF7 treated with MXC, HBCD, NP, OP, and PhIP but Dm values remained above 0.70 . Details of methylation changes by environmental contaminants are shown in Supplementary Table S1.

\subsection{Environmental Contaminants and Collagen Invasion}

In general, the results obtained by visual counting the number of invaded cells, matched the results obtained by spectrophotometry. Almost all agents increased cellular invasiveness to various degrees above the control (both untreated and vehicle; Figure 3).

A
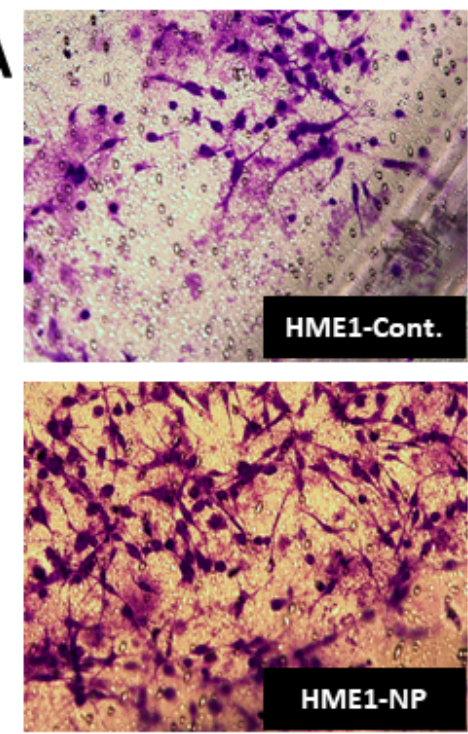
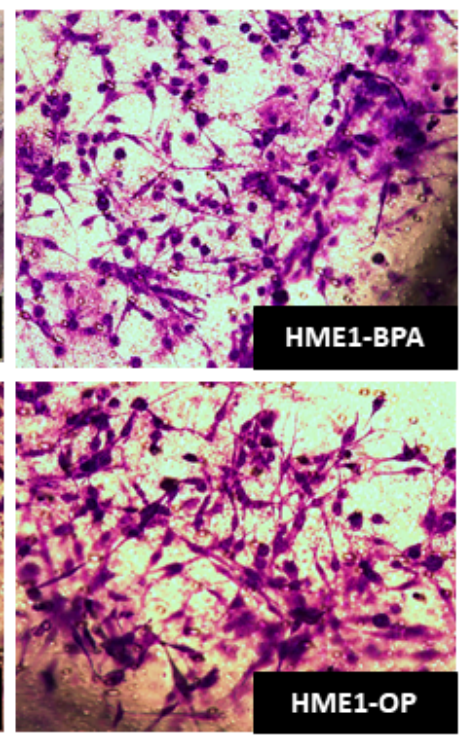

Figure 3. Cont.

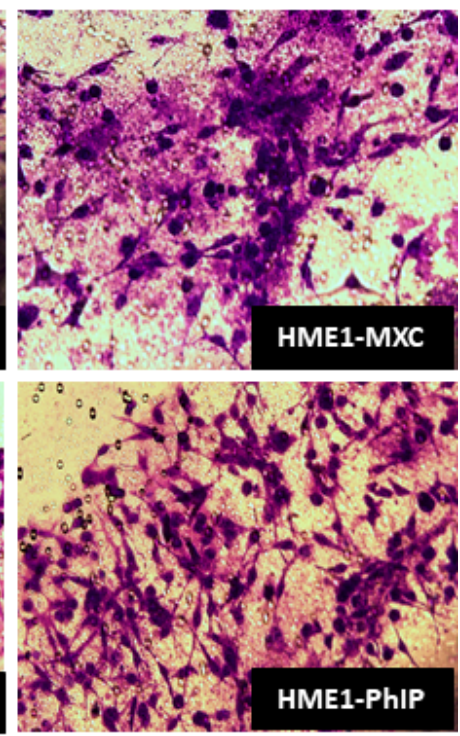

HME1-PhIP

Figure 3. Cont. 
B

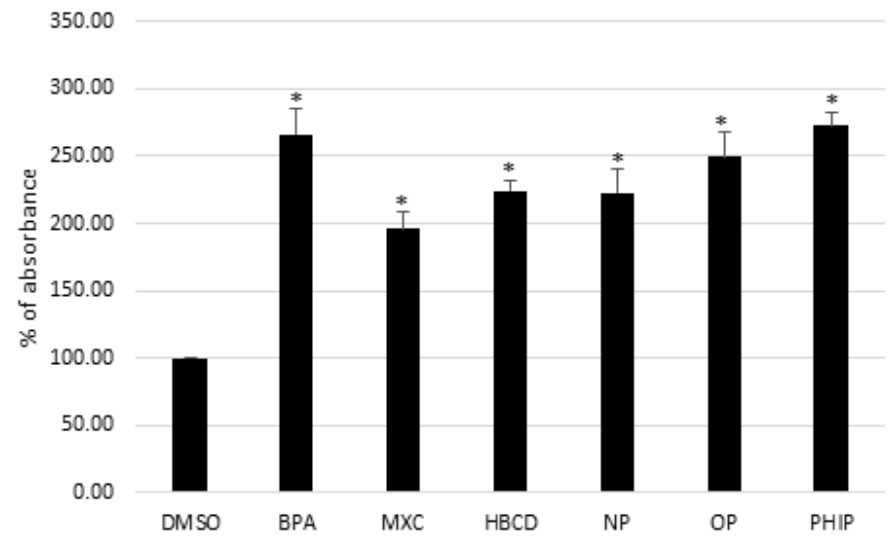

Figure 3. Collagen invasion assay of mammary epithelial cell (HME1) cell line exposed to various chemicals as compared to the base line invasion of control (vehicle-exposed) HME1 cell line. Cells were treated with nanomolar concentrations (BPA, MXC, HBCD, NP, OP, and PhIP at 0.0043, 0.0028, 0.0015, $0.0045,0.0048$, and $0.0044 \mathrm{nM}$, respectively) for two months then cells were serum starved and tested for their ability to invade through college-coated membrane using Boyden chambers. Invaded cells were fixed, stained, and visualized under the microscope and then the dye was eluted and measured using a plate reader. (A) Representative figures to show the differences in invasion potential as detected by microscopic examination. (B) quantitative evaluation of cell invasion as measured by dye elution and spectrophotometric reading at $560 \mathrm{~nm}$. Mean $\pm \mathrm{SEM},{ }^{*} p<0.05, n=3$.

\subsection{Colony Formation in Soft Agar}

Cell Transformation Detection Assay is an anchorage-independent growth assay in soft agar, which is considered the most stringent assay for detecting malignant transformation of cells. This experiment was performed on the 2-months-exposed cells. Some toxic agents showed increased colony formation above the control level in MCF7 cell lines Figure S3, however, none of the HME1 stocks formed colonies in soft agar under the test conditions.

\subsection{Proteomic Analysis (Human Phospho Kinase Array)}

In HME1 there was significant increase in 6 phosphoproteins: Epidermal growth factor receptor (EGFR), cyclic AMP response element binding protein (CREB), the signal transducer and activator of transcription 6 (STAT6), c-Jun, STAT3, and heat shock protein 60 (HSP60); and considerable increase in some others such as heat shock protein 27 (HSP27), 5'-AMP-activated protein kinase catalytic subunit alpha-1 (AMPK $\alpha 1$ ), Focal adhesion kinase (FAK), Glycogen synthase kinase 3 alpha/beta $(\mathrm{GSK} 3 \alpha / \beta)$, Tumor protein p53 (p53), Ribosomal protein S6 kinase beta-1 (S6K1), also known as p70S6 kinase, ribosomal S6 kinase (RSK), Mitogen- and Stress-activated protein Kinases 1 and 2 (MSK1/2), p38 mitogen-activated protein kinases (p38 $\alpha$, MAPK14), and c-Jun N-terminal kinases (JNK1/2) (Figure 4). All of these were induced by either all three or at least two of the tested toxic agents (BPA, OP, HBCD). Interestingly, many of these activated phosphoproteins were not noticed in MCA7 which showed much less induction of phospho kinases as compared to HME1. 


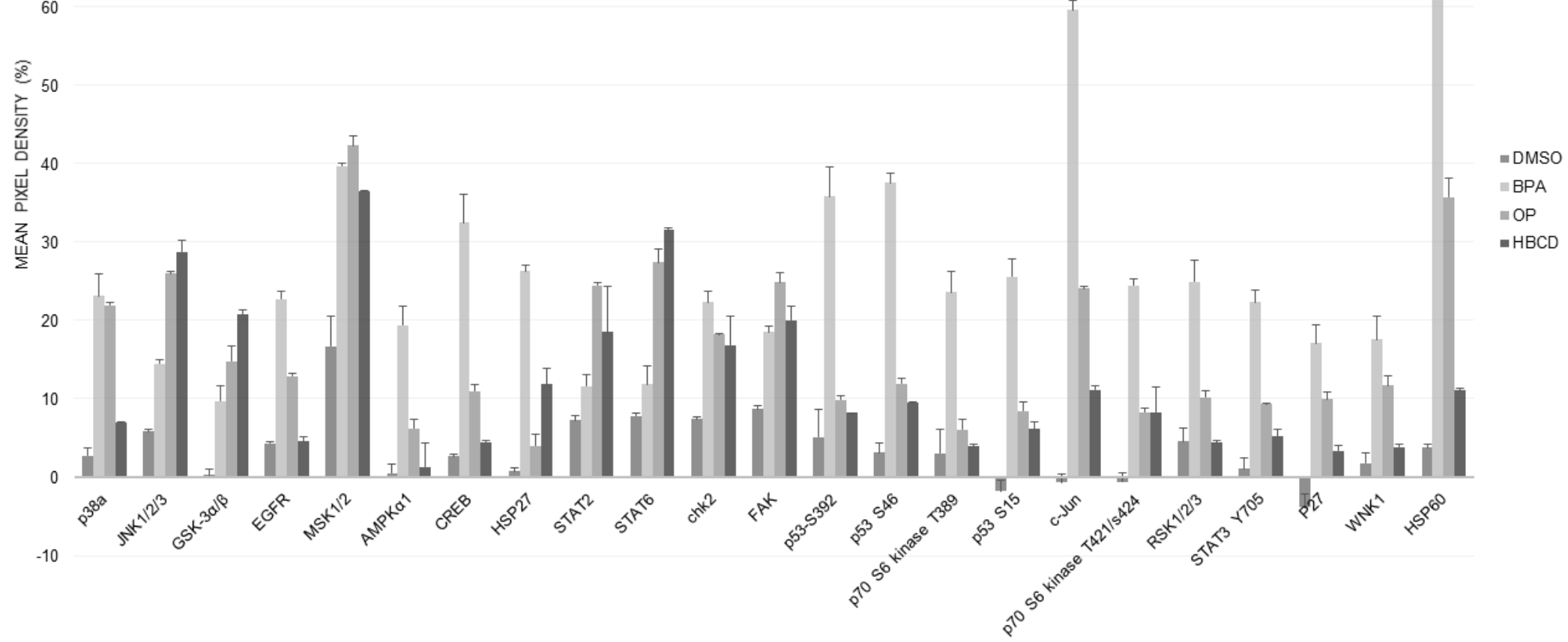

Figure 4. Phospho kinase array analysis after exposure of HME1 to low nanomolar concentrations of three agents (BPA, OP, and HBCD) for two months as compared to the vehicle (DMSO). Whole cell extracts were processed with "human phospho-kinase array" ready-made kit. The array analysis 43 kinase phosphorylation sites and 2 related total proteins with carefully selected specific capture antibodies. (Proteome Profiler; R\&D Systems, Minneapolis, MN, USA). Data were analyzed using "image J" program and the Mean \pm SEM was blotted as percentage (in relation to the positive control spot). Out of the 43 tested proteins, only the proteins which showed a change ratio of at least two times higher than that observed in the vehicle treatment (DMSO) are shown. $n=4$ ( 2 biological $\times 2$ technical). 


\section{Discussion}

In this work, we have generated data which might implicate exposure to low nanomolar concentrations of six common environmental contaminants in breast cancer development.

Some of the tested agents interfered, to variable extent, with the cytotoxicity induced by doxorubicin, suggesting that they could predispose to chemoresistance. These data are consistent with, and adds emphasis on, the published work for BPA [19,20,33,34], the alkylphenols NP and OP [21], and PhIP [30]. Our data are also consistent with the effect of HBCD [35] in breast cancer. Interestingly, in some of the cited references above the described effect was induced by the smallest nanomolar doses. Collectively, these data suggest that low dose of these agents might play a role in breast cancer development through altered viability. These findings may also explain the increasing problem of chemoresistance in breast cancer.

All toxic agents examined here showed potential to induce DNA damage as detected by over-expression of some established markers (pH2AX, pCHK1, pCHK2, p-p53). BPA and OP induced the highest number of DNA damage response markers suggestive of being the most extensive damage inducing agents. The DNA damage was also accompanied by cell cycle disruption marked mainly by arrest at G2/M phase which was bypassed after longer exposures in some instance. The survival of the cells with damaged DNA can predispose to malignant transformation by creating a state of "genomic instability" that accelerates acquisition of further oncogenic mutations [36].

Original mouse data described a pattern of epigenetic alteration dominated by hypomethylation of estrogen target genes, such as Hoxa10 due to low dose exposure to BPA in utero [37]. Global genomic hypomethylation was associated with BPA treatment also in other in vivo models such as zebrafish [38]. In the present work, we used a selected panel of 24 tumor suppressor genes. Our findings showed that some agents induced tumor suppressor gene hypermethylation in this panel.

BPA induced hypermethylation of TIMP3, CHFR, ESR1, and IGSF4 while HBCD induced TIMP3 tumor suppressor gene hypermethylation in MCF7 breast cancer cell line. BPA also induced hypermethylation of CDH13, and GSTP1 in HME1 mammary epithelial cells. In addition, a few loci that were heavily methylated in untreated MCF7 cells decreased in methylation after treatments. Our pattern of hypermethylation and hypomethylation of selected genes resembles that reported by Fernandez et al. (2012) based on MeDIP-on-chip experiments on BPA-exposed MCF-10F breast epithelial cells [39]. Several of those tumor suppressor gene loci that we found hypermethylated after exposure to toxic agents showed frequent hypermethylation in breast cancer cohorts studied previously [40]. Our LINE-1 experiments did not reveal any significant hypomethylation when exposed to toxic chemicals (some mild hypomethylation could be seen).

Interestingly, the accumulated DNA damage and epigenetic alterations, both of which represent an essential base for cellular transformation and cancer development, were accompanied by features of transformed phenotype such as increased cellular invasiveness consistent with some published reports $[15,30,31,41,42]$. Recent literature suggested that BPA can disrupt mammary epithelial cells organization into acinar structures [43], We also observed some increased cellular abilities to form colonies in soft agar (anchorage independent growth) in MCF7 while this effect was not noted in HME1 at the test conditions. Cellular transformation might take prolonged periods and/or increasing doses, or may be, exposure to combination of toxic agents or toxic agents and other condition such as obesity or chronic inflammation. A recent study showed that combined exposures to two of the used agents here (BPA and NP) produced larger effects than the effect of each component applied separately, which could be the case in human life [44]. Even though our in vitro results are unable to explain how these dynamics might work in vivo, it would be difficult to take the lack of colonies formation in HME1 as an evidence against the oncogenicity of these agents in the presence of the accumulation of genetic alterations and increased cellular invasiveness of these cells. Furthermore, the literature data supply multiple evidence about the oncogenicity of BPA and many of these agents [15,30,42,45].

The phosphokinase array data uncovered many phosphoproteins and cellular pathways activated during cellular response to these toxic agents particularly in the mammary epithelial cells (HME1). 
We can generally classify these phosphoproteins into three related groups which form intricate network linking stress response to carcinogenesis. First and most important, many of the identified proteins play a well-established or putative oncogenic role in different stages of mammary carcinogenesis. Examples of these include EGFR, MSK1/2, CREB, FAK, GSK3 $\alpha / \beta$, S6K1/RSK, STAT2, STAT3, and STAT6. MSK1/2 are required for EGF-induced, histone H3-Ser10 phosphorylation and promoter-associated CREB phosphorylation and hence, early c-fos transcription in response to EGF [46]. The detection of these three phosphorylated proteins (EGFR, MSK1/2, CREB) strongly supports a functional consequences marked by EGF pathway transcriptional activity in response to toxic agents which could be an important early step in breast cancer development $[47,48]$. FAK is a cytoplasmic tyrosine kinase that plays critical role in integrin-mediated signal transductions. The activated FAK forms a complex with Src kinases family, which initiates multiple downstream signaling. FAK plays a critical role in cell migration and angiogenesis during cancer progression. EGF/IGF-I induced a co-localization of IGF-IR and FAK, which was evident mostly at the cell membranes of MCF-7 breast cancer cell and caused cell adhesion onto fibronectin, a marker of aggressive breast cancer [49]. The inhibitory phosphorylation of GSK3 $\beta$ might enhance cell proliferation and migration via $\beta$-catenin/cyclin D1 signaling pathway in breast cancer $[50,51]$. Both of p70S6 kinase and STAT3 could exert oncogenic potential in breast cancer through a phosphatidylinositide 3-kinases (PI3K)/Protein kinase B (Akt/PKB)/p70S6 kinase signaling pathway $[52,53]$ while RSK is a family of Ser/Thr protein kinases (RSK1-4) that function downstream of the Ras/mitogen-activated protein kinase (MAPK) signaling to trigger cell survival, growth, and proliferation. Deregulated RSK activity has been associated with multiple cancer types including breast cancer [54].

The second group of induced proteins includes AMPK $\alpha 1$, p38 $\alpha /$ MAPK14, JNK1/2, c-Jun, MSK1/2, CREB, HSP27, and HSP60 all of which could have a role in cellular stress and/or heat shock response. However, more recently, many of these proteins turned out to play an important role in carcinogenesis through an intricate network. The kinases MSK1 and MSK2 are linked to the epidermal growth factor-pathway as discussed above while the p38/MSK1/CREB transcription was shown to have oncogenic potential in some types of cancer [55]. In contrast to the earlier idea that HSPs are induced as a consequence of oncogene activation in cancer, the available literature data suggest that HSP60 is an early biomarker during malignant transformation in many cancers such as those of the breast and colon [56,57]. Researchers showed that bacterial and human HSP60 upregulate EGF, ERK, JNK, and p38/epithelial MAP kinase pathway [58,59]. Mutant EGFR showed the ability to induce HSPs such as HSP60 in lung carcinoma cells [60] suggesting a bidirectional positive feedback loop between HSP60 and EGFR. HSP60 was also reported to interact with and activate $\beta$-catenin [61], and can act as a ligand to Toll like receptor 4 (TLR4) that can activate the NF- $\mathrm{KB}$ pathway which is implicated in tumor development through creating a state chronic inflammation that favor tumor growth [62]. Similarly, an accumulating body of evidence supports a role of HSP27 in carcinogenesis [63].

The third group includes some DNA damage response and DNA repair proteins (p53, Chk2, and p27) which is consistent with and confirms our Western blot data described above.

Some of the pathways mentioned above such as STAT3, EGFR/ERK, HSPs, and DNA repair were reported before in the context of exposure to environmental toxins particularly BPA [42], while the rest of the kinases identified in the current work may be reported for the first time here. Additional oncogenic pathways and mechanisms were reported in the literature. BPA was shown to reduce retinoblastoma-associated protein and increase the Rac1 and CDC24 in normal mouse mammary cultures [64]. BPA was also shown to promote angiogenesis through up regulation of $X$-linked inhibitor of apoptosis via $G$ protein-coupled estrogen receptor pathway [65].

Overall, the available data supply an important evidence to implicate very low doses of six common environmental contaminants in inducing genotoxic/oncogenic alterations in mammary epithelial cells. We elucidated significant pathways upregulated by environmental contaminants which help understanding the mechanisms of action of these toxic agents. These data may explain the remarkable increase in breast cancer incidence and chemoresistance worldwide. 


\section{Materials and Methods}

\subsection{Cell Lines}

MCF-7 cell line was isolated from malignant metastatic pleural effusion of a woman having breast adenocarcinoma. It retains several ideal characteristics particular to the mammary epithelium e.g., positivity for estrogen receptors (ER) and cytokeratin while non-reactive to desmin and vimentin (mesenchymal markers). When grown in vitro, MCF7 can form domes and the epithelial like cells that grow in monolayers with doubling time of $38 \mathrm{~h}$. MCF7 had a wild type p53 gene sequence (American Type Culture Collection, ATCC, Manassas, VA, USA). For this experiment, it was cultured in phenol red free DMEM supplemented with, $1 \mathrm{mM}$ Sodium Pyruvate, $10 \%$ char coal stripped-fetal bovine serum and 1x Penicillin and Streptomycin (Sigma-Aldrich, ST. Louis, MO, USA). hTERT-HME1 (HME1) was from Horizon Discovery (Cambridge, United Kingdom). It was derived from human normal mammary epithelial cells immortalized by stable transfection of hTERT telomerase. It was initially cultured as per the supplier conditions then maintained for the purpose of this experiment in phenol red free DMEM/F12-ham supplemented with 10\% char coal stripped-fetal bovine serum and 1x Penicillin and Streptomycin (Sigma-Aldrich). All cells were maintained at $37^{\circ} \mathrm{C}$ in a humidified $5 \%$ $\mathrm{CO}_{2}$ incubator and were split before their confluency reached $90 \%$ according to supplier instructions.

\subsection{Toxic Chemicals and Viability Assays}

Environmental chemicals tested here were selected on the basis that they have a potential endocrine disrupting effect and/or that they were previously implicated in cancer development. These included BPA, NP, OP, MXC, HBCD, and PhIP. Chemicals were purchased from Sigma-Aldrich Corp. (BPA, NP, OP, and HBCD), Supelco, Bellefonte, PA, USA (MXC); or MP Biomedicals LLC, Solon, OH, USA (PhIP). Chemicals were dissolved in 100\% dimethyl sulfoxide or as recommended and stored as stock solutions at $4{ }^{\circ} \mathrm{C}$. Initially we performed a pilot study to find out the effect of increasing doses of these agents on viability using the standard MTT or Sulforhodamine B (SRB) method as described earlier [66]. For the two-month exposures, cells were seeded in T25 tissue culture flasks without chemicals or DMSO over night to settle and attach then chemicals or DMSO were added next morning. The DMSO concentration did not exceed $1 \%$. Media with fresh chemicals were replaced every 3 days. Cells were split before they reached $90 \%$ confluency. All compounds tested concurrently. Stocks of exposed cells were frozen down in liquid nitrogen after two months. Toxic agents-exposed cells were also tested for viability after overnight exposure to doxorubicin. The IC50 concentration of Doxorubicin was determined as before [66]. Cells were seeded in triplicates in each plate.

\subsection{Detection of DNA Damage Response by Western Blot Analysis}

Cell lysates were made from cultured cells washed twice with ice cold 1X PBS then the pellets were lysed using pre-chilled Triton lysis buffer $(25 \mathrm{mM}$ Tris $\mathrm{HCl}, \mathrm{pH}$ 7.4, $150 \mathrm{mM} \mathrm{NaCl}, 1 \mathrm{mM}$ EDTA, $1 \%$ Triton) to which ( $50 \mathrm{mM} \mathrm{NaF}, 1 \mathrm{mM} \mathrm{Na} 3 \mathrm{VO} 4,1 \mathrm{mM}$ PMSF and $2 \%$ Protease inhibitor) were added freshly, incubated on ice for $5 \mathrm{~min}$ and centrifuged at speed of $14,000 \mathrm{rpm}$ for $10 \mathrm{~min}$ at $4{ }^{\circ} \mathrm{C}$ to remove the cell debris. Protein concentration was quantified using the BCA protein assay (Thermo Fisher Scientific, Waltham, MA, USA). Approximately $30 \mu \mathrm{g}$ of total protein were subjected to SDS-PAGE (7.5\% resolving gel, $4 \%$ stacking gel). The gel, with the separated proteins, was transferred to a PVDF membrane (Bio-Rad Laboratories, Hercules, CA, USA) using a Trans-Blot ${ }^{\circledR}$ TurboTM Blotting system (Bio-Rad) according to the standard transfer protocol. The membrane was blocked for $1 \mathrm{~h}$ at room temperature using 5\% non-fat dry milk (Sigma-Aldrich) in 1x TBST (TBS + 1\% tween), followed by incubation with the primary antibody overnight at $4{ }^{\circ} \mathrm{C}$ on a shaker. Phospho-antibodies were against phospho-Chk1 (Ser345) clone 133D3, phospho-Chk2 (Thr68) clone C13C1, phospho-p53 (Thr18) and phosph- Histone H2A.X (Ser139) clone 20E3 together with their matching antibodies against total proteins, Beta-actin (clone 13E5). All antibodies were from Cell Signaling Technology (Danvers, MA, USA) except phospho-p53 was from Santa Cruz Biotechnology (TX, USA). Primary antibodies were 
used at 1:1000 or at recommended dilutions by suppliers. Next, the membrane was washed with $1 \mathrm{x}$ TBST 3 times for $10 \mathrm{~min}$ each. Then, it was incubated with horseradish peroxidase labeled secondary antibody for $1 \mathrm{~h}$ at room temperature (anti-rabbit IgG HRP-linked antibody at dilution of 1:2000, Cell Signaling). After washing with 1x TBST for 10 min 3 times, the HRP labeled membrane was incubated with substrate (Pierce ${ }^{\mathrm{TM}}$ ECL Western Blotting Substrate, Waltham, MA, USA) for $1 \mathrm{~min}$, exposed to film (Kodak Cl-XPosure TM Film; catalog No: 34090; Company: Thermo Scientific), developed and fixed. Pictures were then evaluated and scanned.

\subsection{Analysis of DNA Content and Cell Cycle Progression}

Cells were seeded at a density of $1 \times 10^{6}$ cells $/ \mathrm{mL}$. After indicated timings, cells are harvested, washed twice with PBS, and then re-suspended in $0.5 \mathrm{~mL}$ ice-cold PBS and later fixed with $4 \mathrm{~mL}$ ice cold $70 \%$ ethanol for $48 \mathrm{~h}$. Cells were then pelleted, washed twice with ice-cold PBS, re-suspended and incubated at room temperature for $30 \mathrm{~min}$ in $0.2 \mathrm{~mL}$ staining buffer supplemented with $50 \mu \mathrm{g}$ RNase and propidium iodide (Sigma-Aldrich) at $50 \mu \mathrm{g} / \mathrm{mL}$ final concentration in the dark. Distribution of cell cycle phases with different DNA contents Cells was analyzed by flowcytometry (BD FACS Aria ${ }^{\mathrm{TM}}$ III, Becton-Dickinson, Franklin Lakes, NJ, USA). Analysis of cell cycle distribution and percentage of cells in G1, S, and G2/M phases of the cell cycle were determined using the cell cycle platform of the FlowJo software v10.6.2 with the Watson pragmatic model (Tree Star, Ashland OR, USA).

\subsection{Methylation Specific Multiplex-Ligation Dependent Probe Amplification (MS-MLPA)}

We used SALSA MS-MLPA Tumor suppressor Kit ME001-C1 (MRC, Amsterdam, Holland) to study promoter methylation of 24 tumor suppressor genes (TSGs) in tumor and normal samples according to manufacturer's instructions (http://www.mrc-holland.com). This kit contains 26 probes for 24 TSGs, which were described in detail in our previous publication [67]. For each reaction, 200-800 ng of DNA was used. Each MS-MLPA reaction generates two aliquots, one undigested and one digested and these can be used for copy number and methylation detection respectively. MS-MLPA utilizes methylation sensitive enzyme HhaI and probes have a recognition sequence against this enzyme. Only templates with methylated HhaI sites, resistant to HhaI cleavage, generate a signal after probe ligation. Amplification products were separated by capillary electrophoresis and analyzed with ABI Prism GeneMapper 4.0 (Applied Biosystems, Waltham, MA, USA). In every assay, normal DNA derived from healthy individuals' lymphocytes was included as a control for the lack of methylation and tumor cell line (RKO) was included as a reference for frequent methylation. Methylation dosage ratios were calculated as described in our previous study [67], in which a value of 0.15 (corresponding to $15 \%$ of methylated DNA) was used as cut-off level for methylation. This analysis was performed on the two-month exposed cells to the low concentration of all agents.

For LINE-1 hypomethylation analysis (MS-MLPA) we followed the protocol described in our previous publication [68]. The custom designed probes target three different areas inside the LINE-1 promoter sequence (L1-1m, L1-2m, L1-3m). These sites were specified in the same reference. Whole genome amplified (WGA) DNA was used as a technical control for low LINE-1 methylation. WGA controls showed decreased LINE-1 methylation below the threshold of 0.70 .

\subsection{Invasion Assay}

For the invasion assay, we used QCMTM High Sensitivity Non-cross-linked Collagen Invasion Assay kits (Merck group, Darmstadt, Germany) and followed the supplied manufacturer protocol. Briefly, the assay was performed using a modified chamber with filter inserts (pore size $8 \mu \mathrm{m}$ ) coated with matrigel in 24-well dishes. Approximately 0.5 million cells were prepared in the corresponding serum-free media. Two hundred and fifty microliters of the cell suspension were added into the inserts (top chamber) and $500 \mu \mathrm{L}$ of $15 \%$ FBS-containing media were added to the bottom chamber. After $48-\mathrm{h}$ incubation, cells remaining in the top chamber were removed and $400 \mu \mathrm{L}$ of cell stain were applied to the invasion chamber insert for $15 \mathrm{~min}$. After several washes with water, the inserts were dried, 
viewed under the microscope, photographed, and the numbers of invaded cells were counted $/ 5$ fields each 200× magnification. Inserts were then transferred into $200 \mu \mathrm{L}$ of extraction buffer and allowed to incubate for $15 \mathrm{~min}$ at room temperature. The dye mixture was then assessed by a plate reader at a wavelength of $630 \mathrm{~nm}$.

\subsection{Colony Formation in Soft Agar}

Colony formation was analyzed using commercial kits (Cell Transformation Detection Assay; Merck group, Darmstadt, Germany). Cells pre-treated with carcinogens or control cells were cultured with appropriate controls in soft agar medium for 21-28 d. HeLa was used as a reference/positive control while the DMSO exposed cells were used as negative control. The, formed colonies were analyzed and counted morphologically using cell stain solution. This analysis was performed on the two-month exposed cells to the low concentration of all agents.

\subsection{Proteome Profile/Human Phospho-Kinase Array}

For molecular pathway analysis we used a "human phospho-kinase array" ready-made kit which analyzes alterations of kinase signaling in response to exposure to selected three agents (BPA, OP, HBCD) which showed the most significant response at most of the previous tests. The array analyses 43 kinase phosphorylation sites and 2 related total proteins with carefully selected specific capture antibodies. The experimental technique and analyses were according to manufacturer's booklet which also contains a list of the targets and phosphorylation sites (Proteome Profiler; R\&D Systems, Minneapolis, MN, USA). This analysis was performed on the two-month exposed HME1 cells to low concentration of BPA, OP, HBCD and vehicle (DMSO). selected results were confirmed by Western blot.

\subsection{Data Analysis:}

We used analysis of variance (one-way ANOVA) for mean comparisons. When the ANOVA test showed statistical differences, the Tukey post hoc test was used to discriminate between groups. $t$-Test was used to calculate significance of 2 independent means. $p$ value of $<0.05$ was considered to determine statistical significance and $0.05<p<0.10$ indicated a tendency.

Supplementary Materials: Supplementary materials can be found at http://www.mdpi.com/1422-0067/21/10/ 3735/s1.

Author Contributions: Conceptualization, W.M.A.-R.; Formal analysis, V.A.N., S.V., P.P., K.B. and W.M.A.-R.; Funding acquisition, W.M.A.-R.; Investigation, V.A.N., S.V., P.P., K.B. and W.M.A.-R.; Methodology, V.A.N., S.V. and W.M.A.-R.; Project administration, W.M.A.-R.; Resources, P.P. and W.M.A.-R.; Supervision, P.P. and W.M.A.-R.; Validation, V.A.N., K.B. and W.M.A.-R.; Writing-original draft, W.M.A.-R.; Writing-review and editing, V.A.N., S.V., P.P., K.B. and W.M.A.-R. All authors have read and agreed to the published version of the manuscript.

Funding: This research was funded by the University of Sharjah grant \# 15010501010-P, Al Jalila Foundation grant \# AJF201446 and Terry Fox Foundation for Cancer Research in the UAE to WMA-R.

Acknowledgments: The authors thank Aravind S.R., Asha Caroline, Harini Kumar, Anju Suresh, and Saila Saarinen for technical assistance; Samrein Ahmed for supplying a buffer recipe.

Conflicts of Interest: The authors declare no conflict of interest. The funders had no role in the design of the study; in the collection, analyses, or interpretation of data; in the writing of the manuscript, or in the decision to publish the results.

\section{References}

1. Bray, F.; Ferlay, J.; Soerjomataram, I.; Siegel, R.L.; Torre, L.A.; Jemal, A. Global cancer statistics 2018: GLOBOCAN estimates of incidence and mortality worldwide for 36 cancers in 185 countries. CA Cancer J. Clin. 2018, 68, 394-424. [CrossRef] [PubMed]

2. Azubuike, S.O.; Muirhead, C.; Hayes, L.; McNally, R. Rising global burden of breast cancer: The case of sub-Saharan Africa (with emphasis on Nigeria) and implications for regional development: A review. World J. Surg. Oncol. 2018, 16, 63. [CrossRef] [PubMed] 
3. Rivera-Franco, M.M.; Leon-Rodriguez, E. Delays in Breast Cancer Detection and Treatment in Developing Countries. Breast Cancer (Auckl) 2018, 12. [CrossRef] [PubMed]

4. Dey, S.; Soliman, A.S.; Hablas, A.; Seifeldein, I.A.; Ismail, K.; Ramadan, M.; El-Hamzawy, H.; Wilson, M.L.; Banerjee, M.; Boffetta, P.; et al. Urban-rural differences in breast cancer incidence in Egypt (1999-2006). Breast 2010, 19, 417-423. [CrossRef] [PubMed]

5. McDonald, J.T.; Farnworth, M.; Liu, Z. Cancer and the healthy immigrant effect: A statistical analysis of cancer diagnosis using a linked Census-cancer registry administrative database. BMC Public Health 2017, 17, 296. [CrossRef] [PubMed]

6. Peto, J. Cancer epidemiology in the last century and the next decade. Nature 2001, 411, 390-395. [CrossRef]

7. Abdel-Rahman, W.M.; Moustafa, Y.M.; Ahmed, B.O.; Mostafa, R.M. Endocrine disruptors and breast cancer risk-time to consider the environment. Asian Pac. J. Cancer Prev. 2012, 13, 5937-5946. [CrossRef]

8. Ho, V.; Brunetti, V.; Peacock, S.; Massey, T.E.; Godschalk, R.W.L.; van Schooten, F.J.; Ashbury, J.E.; Vanner, S.J.; King, W.D. Exposure to meat-derived carcinogens and bulky DNA adduct levels in normal-appearing colon mucosa. Mutat. Res. 2017, 821, 5-12. [CrossRef]

9. Chiavarini, M.; Bertarelli, G.; Minelli, L.; Fabiani, R. Dietary Intake of Meat Cooking-Related Mutagens (HCAs) and Risk of Colorectal Adenoma and Cancer: A Systematic Review and Meta-Analysis. Nutrients 2017, 9, 514. [CrossRef]

10. Chen, J.X.; Wang, H.; Liu, A.; Zhang, L.; Reuhl, K.; Yang, C.S. From the Cover: PhIP/DSS-Induced Colon Carcinogenesis in CYP1A-Humanized Mice and the Possible Role of Lgr5+ Stem Cells. Toxicol. Sci. 2017, 155, 224-233. [CrossRef]

11. Gould, J.C.; Leonard, L.S.; Maness, S.C.; Wagner, B.L.; Conner, K.; Zacharewski, T.; Safe, S.; McDonnell, D.P.; Gaido, K.W. Bisphenol A interacts with the estrogen receptor alpha in a distinct manner from estradiol. Mol. Cell. Endocrinol. 1998, 142, 203-214. [CrossRef]

12. Kim, H.S.; Han, S.Y.; Yoo, S.D.; Lee, B.M.; Park, K.L. Potential estrogenic effects of bisphenol-A estimated by in vitro and in vivo combination assays. J. Toxicol. Sci. 2001, 26, 111-118. [CrossRef] [PubMed]

13. Dong, S.; Terasaka, S.; Kiyama, R. Bisphenol A induces a rapid activation of Erk1/2 through GPR30 in human breast cancer cells. Environ. Pollut. 2011, 159, 212-218. [CrossRef] [PubMed]

14. Quesada, I.; Fuentes, E.; Viso-Leon, M.C.; Soria, B.; Ripoll, C.; Nadal, A. Low doses of the endocrine disruptor bisphenol-A and the native hormone 17beta-estradiol rapidly activate transcription factor CREB. FASEB J. 2002, 16, 1671-1673. [CrossRef]

15. Wang, Z.; Liu, H.; Liu, S. Low-Dose Bisphenol A Exposure: A Seemingly Instigating Carcinogenic Effect on Breast Cancer. Adv. Sci. (Weinh) 2016, 4, 1600248. [CrossRef]

16. Hafezi, S.A.; Abdel-Rahman, W.M. The Endocrine Disruptor Bisphenol A (BPA) Exerts a Wide Range of Effects in Carcinogenesis and Response to Therapy. Curr. Mol. Pharm. 2019, 12, 230-238. [CrossRef]

17. Kim, H.; Kim, H.S.; Moon, W.K. Comparison of transcriptome expression alterations by chronic exposure to low-dose bisphenol A in different subtypes of breast cancer cells. Toxicol. Appl. Pharmacol. 2019, 385, 114814. [CrossRef]

18. Lloyd, V.; Morse, M.; Purakal, B.; Parker, J.; Benard, P.; Crone, M.; Pfiffner, S.; Szmyd, M.; Dinda, S. Hormone-Like Effects of Bisphenol A on p53 and Estrogen Receptor Alpha in Breast Cancer Cells. BioRes. Open Access 2019, 8, 169-184. [CrossRef]

19. LaPensee, E.W.; LaPensee, C.R.; Fox, S.; Schwemberger, S.; Afton, S.; Ben-Jonathan, N. Bisphenol A and estradiol are equipotent in antagonizing cisplatin-induced cytotoxicity in breast cancer cells. Cancer Lett. 2010, 290, 167-173. [CrossRef]

20. Lapensee, E.W.; Tuttle, T.R.; Fox, S.R.; Ben-Jonathan, N. Bisphenol A at low nanomolar doses confers chemoresistance in estrogen receptor-alpha-positive and -negative breast cancer cells. Environ. Health Perspect. 2009, 117, 175-180. [CrossRef]

21. Chamard-Jovenin, C.; Thiebaut, C.; Chesnel, A.; Bresso, E.; Morel, C.; Smail-Tabbone, M.; Devignes, M.D.; Boukhobza, T.; Dumond, H. Low-Dose Alkylphenol Exposure Promotes Mammary Epithelium Alterations and Transgenerational Developmental Defects, But Does Not Enhance Tumorigenic Behavior of Breast Cancer Cells. Front. Endocrinol. (Lausanne) 2017, 8, 272. [CrossRef] [PubMed]

22. Ajj, H.; Chesnel, A.; Pinel, S.; Plenat, F.; Flament, S.; Dumond, H. An alkylphenol mix promotes seminoma derived cell proliferation through an ERalpha36-mediated mechanism. PLoS ONE 2013, 8, e61758. [CrossRef] [PubMed] 
23. Park, M.A.; Hwang, K.A.; Lee, H.R.; Yi, B.R.; Choi, K.C. Cell Growth of BG-1 Ovarian Cancer Cells was Promoted by 4-Tert-octylphenol and 4-Nonylphenol via Downregulation of TGF-beta Receptor 2 and Upregulation of c-myc. Toxicol. Res. 2011, 27, 253-259. [CrossRef] [PubMed]

24. Kim, J.Y.; Yi, B.R.; Go, R.E.; Hwang, K.A.; Nam, K.H.; Choi, K.C. Methoxychlor and triclosan stimulates ovarian cancer growth by regulating cell cycle- and apoptosis-related genes via an estrogen receptor-dependent pathway. Environ. Toxicol. Pharm. 2014, 37, 1264-1274. [CrossRef]

25. Eldakroory, S.A.; Morsi, D.E.; Abdel-Rahman, R.H.; Roshdy, S.; Gouida, M.S.; Khashaba, E.O. Correlation between toxic organochlorine pesticides and breast cancer. Hum. Exp. Toxicol. 2017, 36, 1326-1334. [CrossRef]

26. Li, R.J.; Gao, H.; Na, G.S.; Lu, Z.H.; Yao, Y.; Yang, F. Hexabromocyclododecane-induced Genotoxicity in Cultured Human Breast Cells through DNA Damage. Biomed. Environ. Sci. 2017, 30, 296-300.

27. Kim, S.H.; Nam, K.H.; Hwang, K.A.; Choi, K.C. Influence of hexabromocyclododecane and 4-nonylphenol on the regulation of cell growth, apoptosis and migration in prostatic cancer cells. Toxicol. In Vitro 2016, 32, 240-247. [CrossRef]

28. Park, M.A.; Hwang, K.A.; Lee, H.R.; Yi, B.R.; Jeung, E.B.; Choi, K.C. Cell growth of BG-1 ovarian cancer cells is promoted by di-n-butyl phthalate and hexabromocyclododecane via upregulation of the cyclin $\mathrm{D}$ and cyclin-dependent kinase-4 genes. Mol. Med. Rep. 2012, 5, 761-766.

29. An, J.; Wang, X.; Guo, P.; Zhong, Y.; Zhang, X.; Yu, Z. Hexabromocyclododecane and polychlorinated biphenyls increase resistance of hepatocellular carcinoma cells to cisplatin through the phosphatidylinositol 3-kinase/protein kinase B pathway. Toxicol. Lett. 2014, 229, 265-272. [CrossRef]

30. Choudhary, S.; Sood, S.; Donnell, R.L.; Wang, H.C. Intervention of human breast cell carcinogenesis chronically induced by 2-amino-1-methyl-6-phenylimidazo[4,5-b]pyridine. Carcinogenesis 2012, 33, 876-885. [CrossRef]

31. Papaioannou, M.D.; Koufaris, C.; Gooderham, N.J. The cooked meat-derived mammary carcinogen 2-amino-1-methyl-6-phenylimidazo[4,5-b]pyridine (PhIP) elicits estrogenic-like microRNA responses in breast cancer cells. Toxicol. Lett. 2014, 229, 9-16. [CrossRef] [PubMed]

32. Gu, D.; Turesky, R.J.; Tao, Y.; Langouet, S.A.; Nauwelaers, G.C.; Yuan, J.M.; Yee, D.; Yu, M.C. DNA adducts of 2-amino-1-methyl-6-phenylimidazo[4,5-b]pyridine and 4-aminobiphenyl are infrequently detected in human mammary tissue by liquid chromatography/tandem mass spectrometry. Carcinogenesis 2012, 33, 124-130. [CrossRef] [PubMed]

33. Mlynarcikova, A.; Macho, L.; Fickova, M. Bisphenol A alone or in combination with estradiol modulates cell cycle- and apoptosis-related proteins and genes in MCF7 cells. Endocr. Regul. 2013, 47, 189-199. [CrossRef] [PubMed]

34. Delgado, M.; Ribeiro-Varandas, E. Bisphenol A at the reference level counteracts doxorubicin transcriptional effects on cancer related genes in HT29 cells. Toxicol. In Vitro 2015, 29, 2009-2014. [CrossRef]

35. Dorosh, A.; Ded, L.; Elzeinova, F.; Peknicova, J. Assessing oestrogenic effects of brominated flame retardants hexabromocyclododecane and tetrabromobisphenol A on MCF-7 cells. Folia Biol. (Praha) 2011, 57, 35-39.

36. Abdel-Rahman, W.M. Genomic instability and carcinogenesis: An update. Curr. Genom. 2008, 9, 535-541. [CrossRef]

37. Bromer, J.G.; Zhou, Y.; Taylor, M.B.; Doherty, L.; Taylor, H.S. Bisphenol-A exposure in utero leads to epigenetic alterations in the developmental programming of uterine estrogen response. FASEB J. 2010, 24, 2273-2280. [CrossRef]

38. Laing, L.V.; Viana, J.; Dempster, E.L.; Trznadel, M.; Trunkfield, L.A.; Uren Webster, T.M.; van Aerle, R.; Paull, G.C.; Wilson, R.J.; Mill, J.; et al. Bisphenol A causes reproductive toxicity, decreases dnmt1 transcription, and reduces global DNA methylation in breeding zebrafish (Danio rerio). Epigenetics 2016, 11, 526-538. [CrossRef]

39. Fernandez, S.V.; Huang, Y.; Snider, K.E.; Zhou, Y.; Pogash, T.J.; Russo, J. Expression and DNA methylation changes in human breast epithelial cells after bisphenol A exposure. Int. J. Oncol. 2012, 41, 369-377. [CrossRef]

40. Lotsari, J.E.; Gylling, A.; Abdel-Rahman, W.M.; Nieminen, T.T.; Aittomaki, K.; Friman, M.; Pitkanen, R.; Aarnio, M.; Jarvinen, H.J.; Mecklin, J.P.; et al. Breast carcinoma and Lynch syndrome: Molecular analysis of tumors arising in mutation carriers, non-carriers, and sporadic cases. Breast Cancer Res. 2012, 14, R90. [CrossRef] 
41. Goodson, W.H., 3rd; Luciani, M.G.; Sayeed, S.A.; Jaffee, I.M.; Moore, D.H., 2nd; Dairkee, S.H. Activation of the mTOR pathway by low levels of xenoestrogens in breast epithelial cells from high-risk women. Carcinogenesis 2011, 32, 1724-1733. [CrossRef] [PubMed]

42. Gao, H.; Yang, B.J.; Li, N.; Feng, L.M.; Shi, X.Y.; Zhao, W.H.; Liu, S.J. Bisphenol A and hormone-associated cancers: Current progress and perspectives. Medicine 2015, 94, e211. [CrossRef] [PubMed]

43. Atlas, E.; Dimitrova, V. Bisphenol S and Bisphenol A disrupt morphogenesis of MCF-12A human mammary epithelial cells. Sci. Rep. 2019, 9, 16005. [CrossRef] [PubMed]

44. Mao, W.; Song, Y.; Sui, H.; Cao, P.; Liu, Z. Analysis of individual and combined estrogenic effects of bisphenol, nonylphenol and diethylstilbestrol in immature rats with mathematical models. Environ. Health Prev. Med. 2019, 24, 32. [CrossRef] [PubMed]

45. Dairkee, S.H.; Seok, J.; Champion, S.; Sayeed, A.; Mindrinos, M.; Xiao, W.; Davis, R.W.; Goodson, W.H. Bisphenol A induces a profile of tumor aggressiveness in high-risk cells from breast cancer patients. Cancer Res. 2008, 68, 2076-2080. [CrossRef] [PubMed]

46. Duncan, E.A.; Anest, V.; Cogswell, P.; Baldwin, A.S. The kinases MSK1 and MSK2 are required for epidermal growth factor-induced, but not tumor necrosis factor-induced, histone H3 Ser10 phosphorylation. J. Biol. Chem. 2006, 281, 12521-12525. [CrossRef] [PubMed]

47. Menard, S.; Casalini, P.; Campiglio, M.; Pupa, S.M.; Tagliabue, E. Role of HER2/neu in tumor progression and therapy. Cell. Mol. Life Sci. 2004, 61, 2965-2978.

48. Kyriakopoulou, K.; Kefali, E.; Piperigkou, Z.; Bassiony, H.; Karamanos, N.K. Advances in targeting epidermal growth factor receptor signaling pathway in mammary cancer. Cell. Signal. 2018, 51, 99-109. [CrossRef]

49. Voudouri, K.; Nikitovic, D.; Berdiaki, A.; Kletsas, D.; Karamanos, N.K.; Tzanakakis, G.N. IGF-I/EGF and E2 signaling crosstalk through IGF-IR conduit point affects breast cancer cell adhesion. Matrix Biol. 2016, 56, 95-113. [CrossRef]

50. Gao, S.; Ge, A.; Xu, S.; You, Z.; Ning, S.; Zhao, Y.; Pang, D. PSAT1 is regulated by ATF4 and enhances cell proliferation via the GSK3beta/beta-catenin/cyclin D1 signaling pathway in ER-negative breast cancer. J. Exp. Clin. Cancer Res. 2017, 36, 179. [CrossRef]

51. Song, N.; Zhong, J.; Hu, Q.; Gu, T.; Yang, B.; Zhang, J.; Yu, J.; Ma, X.; Chen, Q.; Qi, J.; et al. FGF18 Enhances Migration and the Epithelial-Mesenchymal Transition in Breast Cancer by Regulating Akt/GSK3beta/Beta-Catenin Signaling. Cell. Physiol. Biochem. 2018, 49, 1019-1032. [CrossRef] [PubMed]

52. Halacli, S.O.; Dogan, A.L. FOXP1 regulation via the PI3K/Akt/p70S6K signaling pathway in breast cancer cells. Oncol. Lett. 2015, 9, 1482-1488. [CrossRef] [PubMed]

53. Zhang, L.D.; Chen, L.; Zhang, M.; Qi, H.J.; Chen, L.; Chen, H.F.; Zhong, M.K.; Shi, X.J.; Li, Q.Y. Downregulation of ERRalpha inhibits angiogenesis in human umbilical vein endothelial cells through regulating VEGF production and PI3K/Akt/STAT3 signaling pathway. Eur. J. Pharm. 2015, 769, 167-176. [CrossRef] [PubMed]

54. Houles, T.; Roux, P.P. Defining the role of the RSK isoforms in cancer. Semin. Cancer Biol. 2018, 48, 53-61. [CrossRef] [PubMed]

55. Lee, H.Y.; Crawley, S.; Hokari, R.; Kwon, S.; Kim, Y.S. Bile acid regulates MUC2 transcription in colon cancer cells via positive EGFR/PKC/Ras/ERK/CREB, PI3K/Akt/IkappaB/NF-kappaB and p38/MSK1/CREB pathways and negative JNK/c-Jun/AP-1 pathway. Int. J. Oncol. 2010, 36, 941-953.

56. Calderwood, S.K. Heat shock proteins and cancer: Intracellular chaperones or extracellular signalling ligands? Philos. Trans. R. Soc. B Biol. Sci. 2018, 373. [CrossRef]

57. Rappa, F.; Pitruzzella, A.; Marino Gammazza, A.; Barone, R.; Mocciaro, E.; Tomasello, G.; Carini, F.; Farina, F.; Zummo, G.; Conway de Macario, E.; et al. Quantitative patterns of Hsps in tubular adenoma compared with normal and tumor tissues reveal the value of Hsp10 and Hsp60 in early diagnosis of large bowel cancer. Cell Stress Chaperones 2016, 21, 927-933. [CrossRef]

58. Zhang, L.; Koivisto, L.; Heino, J.; Uitto, V.J. Bacterial heat shock protein 60 may increase epithelial cell migration through activation of MAP kinases and inhibition of alpha6beta4 integrin expression. Biochem. Biophys. Res. Commun. 2004, 319, 1088-1095. [CrossRef]

59. Zhang, L.; Pelech, S.L.; Mayrand, D.; Grenier, D.; Heino, J.; Uitto, V.J. Bacterial heat shock protein-60 increases epithelial cell proliferation through the ERK1/2 MAP kinases. Exp. Cell Res. 2001, 266, 11-20. [CrossRef]

60. Kamath, A.; Joseph, A.M.; Gupta, K.; Behera, D.; Jaiswal, A.; Dewan, R.; Rajala, M.S. Proteomic analysis of HEK293 cells expressing non small cell lung carcinoma associated epidermal growth factor receptor variants reveals induction of heat shock response. Exp. Hematol. Oncol. 2015, 4, 16. [CrossRef] 
61. Tsai, Y.P.; Yang, M.H.; Huang, C.H.; Chang, S.Y.; Chen, P.M.; Liu, C.J.; Teng, S.C.; Wu, K.J. Interaction between HSP60 and beta-catenin promotes metastasis. Carcinogenesis 2009, 30, 1049-1057. [CrossRef] [PubMed]

62. Chow, M.T.; Moller, A.; Smyth, M.J. Inflammation and immune surveillance in cancer. Semin. Cancer Biol. 2012, 22, 23-32. [CrossRef]

63. Saini, J.; Sharma, P.K. Clinical, Prognostic and Therapeutic Significance of Heat Shock Proteins in Cancer. Curr. Drug Targets 2018, 19, 1478-1490. [CrossRef] [PubMed]

64. Williams, K.E.; Lemieux, G.A.; Hassis, M.E.; Olshen, A.B.; Fisher, S.J.; Werb, Z. Quantitative proteomic analyses of mammary organoids reveals distinct signatures after exposure to environmental chemicals. Proc. Natl. Acad. Sci. USA 2016, 113, E1343-E1351. [CrossRef] [PubMed]

65. Liu, J.; Jin, X.; Zhao, N.; Ye, X.; Ying, C. Bisphenol A promotes X-linked inhibitor of apoptosis protein-dependent angiogenesis via $\mathrm{G}$ protein-coupled estrogen receptor pathway. J. Appl. Toxicol. 2015, 35, 1309-1317. [CrossRef] [PubMed]

66. Abdel-Rahman, W.M.; Al-Khayyal, N.A.; Nair, V.A.; Aravind, S.R.; Saber-Ayad, M. Role of AXL in invasion and drug resistance of colon and breast cancer cells and its association with p53 alterations. World J. Gastroenterol. 2017, 23, 3440-3448. [CrossRef] [PubMed]

67. Joensuu, E.I.; Abdel-Rahman, W.M.; Ollikainen, M.; Ruosaari, S.; Knuutila, S.; Peltomaki, P. Epigenetic signatures of familial cancer are characteristic of tumor type and family category. Cancer Res. 2008, 68, 4597-4605. [CrossRef]

68. Pavicic, W.; Joensuu, E.I.; Nieminen, T.; Peltomaki, P. LINE-1 hypomethylation in familial and sporadic cancer. J. Mol. Med. (Berl. Ger.) 2012, 90, 827-835. [CrossRef]

(C) 2020 by the authors. Licensee MDPI, Basel, Switzerland. This article is an open access article distributed under the terms and conditions of the Creative Commons Attribution (CC BY) license (http://creativecommons.org/licenses/by/4.0/). 